\title{
Determinants of Youth Unemployment: Evidence from Jordan
}

Submitted $12 / 07 / 20,1^{\text {st }}$ revision $11 / 08 / / 20,2^{\text {nd }}$ revision $11 / 09 / 20$, accepted $30 / 09 / 20$

\begin{abstract}
Akram Sh. Alawad ${ }^{1}$, Fuad Kreishan ${ }^{2}$, Mohammad Selim ${ }^{3}$
Abstract:

Purpose: This study's main objective is to identify and analyze the main determinants of youth unemployment in Jordan.

Design/Approach/Methodology: The study employs a Multinomial logistic regression model (MLM) to analyze the determinants of youth unemployment in Jordan using data based on the Jordan labor market panel survey (JLMPS) in 2016, which was conducted by the Department of Statistics (DOS).

Findings: The study finds that youth employment in Jordan is influenced by gender, educational level, geographical location, and marital status. According to the youths covered by this study, male youth stand a better chance of being employed than the female counterpart. Therefore, special attention must be paid to integrating the youth and particularly females better into the labor market for increasing the prospect of their employment.

Practical Implication: The results can be used to mitigate the problems of youth unemployment, especially female youth unemployment, in Jordan and other Arab countries. Policymakers must focus on certain constraints, such as mobility and cultural factors, as roadblocks that may cause relatively higher youth female unemployment.

Originality/Value: This is one of the latest attempts to identify, investigate, and analyze the causes of youth unemployment in Jordan. The study adds to scholarly debate on youth unemployment's main determinants by giving evidence from a developing country. However, this study unveils a unique feature of youth unemployment in Jordan; this study will bridge the literature gap, especially for Jordan, and help improve overall youth unemployment.
\end{abstract}

Keywords: Unemployment, youth, labor market, human capital, Jordan.

JEL Classifications: I21, I25, J24.

Paper type: Research article.

\footnotetext{
${ }^{1}$ Department of Economics, College of Business Administration, Al-Hussein Bin Talal

University, Jordan, E-mail: Akram.alawad@yahoo.com;

${ }^{2}$ Corresponding author, Department of Economics, College of Business

Administration, Al-Hussein Bin Talal University, Jordan,

E-mail: fuadkreishan@gmail.com

${ }^{3}$ Department of Economics and Finance, College of Business Administration,

University of Bahrain, Sakhir, Bahrain,

E-mail: mselim@uob.edu.bh
} 


\section{Introduction}

Youth unemployment is among the major problems facing both developed and developing countries. In fact, youth unemployment is more critical to developing countries because of the incidence of high poverty, which virtually forces all members of the household to work to ensure survival (International Labour Organization (ILO), 2011). Youth unemployment has become a threat to society in all aspects, socially, economically, and politically in most developing countries. Socially, youth unemployment is not only of concern to the unemployed ones but also to the whole society. It is the expectation of most youth people to find employment, especially after graduation. Failure to find employment results in demoralization, depreciation in their human capital, and deterioration in their employment prospects, which leads to social exclusion (Clark and Summers, 1982). Economically youth unemployment has led to the labor market instability, increased living costs, erosion of the tax base, and unutilized investments in education and training (ILO, 2011). Politically, according to Keen (2002), numerous studies argue that youth unemployment is the main cause of political stability and conflicts of nations. In fact, many researchers see youth unemployment as the major reason behind the last 10 years of popular uprisings in many Arab countries and Jordan, is no exception in this regard (Prince et al., 2018).

Although unemployment is a global issue, the situation in Middle Eastern countries is getting worse mainly due to the unbalanced relationship between the rate of economic growth and the high population growth rate, and hence the unemployment rate continues to rise. Jordan is no exception in this regard. The unemployment situation in Jordan is particularly worrying against the background that youths represent a large population. Recently, youth unemployment is a pressing issue in Jordan, where the unemployment rate reached (19\%) during 2019, according to a report released by the (DOS). The situation for youths is even more challenging, as Jordan has almost two-thirds of the population younger than (30) years and thirtytwo percent of youth aged (15-30) are unemployed every year, more than (100.000) young people in Jordan start looking for work. However, this year, the figure is expected to rise sharply as the country has been under total lockdown since March 2020, after just a few COVID-19 cases appeared around the country in March 2020.

Logically, a high level of unemployment indicates the failure of a country's economy to use its labor resources effectively. In general, there are various factors explaining unemployment, such as a low level of general economic activity, recession, inflation, rapid changes in technology, disability, willingness to work, and discrimination. In the case of Jordan, several factors contribute to the causes of youth unemployment. According to Mryyan (2014), at least three structural problems explain the persistence of high youth unemployment. First, the mismatch between education outputs and the labor market's skills cause high unemployment among university graduates. In contrast, labor market participation among high-skilled youth is particularly low; young graduates are likely to face an average labor market 
transition of three years. Second, the inability of both the private and public sectors to absorb new market labor entrants. Third, lacking access to and quality national programs enables a smooth school-to-work transition, including vocational training and career guidance.

The analysis of information on the determinants of youth unemployment is critical to the government and policymaker in addressing polices to reduce unemployment rates and promote youth employment. This issue is also important to the employers and other labor market players for understanding the source of problems resulting in the unemployment of youth, which accounts for a large share of the Jordanian labor force of occupational status and unemployment is therefore essential both in tackling the present difficulties and foreseeing future changes. Therefore, the goal of this study is to analyze so we can identify the various possible factors associated with youth unemployment in Jordan. The importance of this study is that it aims to provide a better understanding of the potential determinants leading to youth employment. It employs the micro-level data from Jordan labor market panel surveys (JLMPS, 2016). The study also adds to the literature by filling the knowledge gaps by considering several key variables leading to youth unemployment and how it can be treated in the country.

The remainder of the paper is organized as follows: Section 2 presents the literature review; Section 3 presents the methodology and data used; Section 4 examines the relationship between demographic characteristics and youth unemployment in Jordan empirically, puts forth the main results; Section 5 concludes and presents recommendations.

\section{Literature Review}

What causes youth unemployment has been a major concern to policymakers, scholars, and other development stakeholders. Several factors, such as economic, social, political, and regional factors have been related to youth unemployment in several studies. Msigwa and Kipesha (2013) explain that unemployment is a multidimensional concept which involves economic, political, and social dimensions, and it is a difficult concept to define. According to Contini (2010), youth unemployment is a function of a given country's economic condition, labor market, and labor policies. A country with high economic growth and economic development is likely to create more jobs due to output increases, which require additional labor force. According to ILO (2006), well-designed labor market regulations in the country are significant in the production of employment to both the country's youth and adult population. The youth unemployment has also been linked with educational background and qualification possessed by the young people compared to the qualification required in the labor market. There has been a skill mismatch between the youth and the labor market, which increases youth unemployment (Dimian, 2011; OECD, 2006). Regarding reducing youth unemployment, Speckesser et al. (2019) found that wage subsidies and job creation 
programs contributed to reducing youth unemployment in Europe. According to ILO (2011), youth unemployment is related to low school leaving age and low economic activities where the business environment does not support the easy startup. UNICEF (2005) indicated that youth people are not completing secondary education or other vocational training in most developing countries. Youth unemployment has also been related to family background, Pozzoli, (2009), experience gap (Caroleo and Pastore, 2007) as well as many demographic related factors (Green et al., 2001).

One of the first analyses of the unemployed youth's characteristics is provided by Feldstein and Ellwood (1979). They find that a male in America teenage unemployment is concentrated in a group that experiences long periods of unemployment. This group is characterized by a low level of education and low family income. Similarly, the importance of personal characteristics is further highlighted in a study by Andrews and Bradley (1997). The authors use a multinomial logit analysis on cross-section data of all school leavers in Lancashire in 1991 and find that the chance of becoming unemployed is the greatest for the least able with no formal qualifications and for those who have been too large schools with lower academic achievements. As a policy initiative, they suggest subsidies to encourage young people to obtain intermediate skills and employers to value this kind of labor more highly. Extending on the previous analysis, Viitanen (1999) investigates the personal, regional, and family background characteristics of the unemployed youth using data from the General Household Survey. The main result noted that the variables which are found to be significant for both sexes include no qualifications, parental unemployment, and rented accommodation.

A study by Msigwa and Kipesha (2013) examined the factors determining youth unemployment in Tanzania using (MLM). The study's findings show that gender, geographical location, education, skills, and marital status are all significant factors in explaining the difference in youth unemployment in Tanzania. In Africa also, Ndagijimana et al. (2018) shed light on the determinants of youth employment status in Rwanda using the multinomial logit model. after analysis of the data used, the study suggested that youth employment in Rwanda is influenced by gender, age, education, and geographical location and based on its findings it provided policy recommendations to promote youth employment.

A recent study by Rahman et al. (2020) has found that skills mismatch is one of the most important causes of youth unemployment and suggests that the country must change its education system according to the growing demand for skills. It is important to note that real GDP is negatively affected during the financial crises or economic crises like the current COVID-19 crisis, but the negative effect is relatively harsh on youth unemployment compared to the overall unemployment rate. Choudhry et al. (2012) found that financial crises contributed significantly to the rise of youth unemployment. Therefore, to address rising youth unemployment, special attention must be paid because youth unemployment is somewhat more 
unique and has different dimensions, such as gender, experience, and dependability factors.

Other international evidence on youth unemployment includes the study by Dimitrov (2012), which examined youth unemployment in Bulgaria. The study reported that factors such as early school leaving age, low education quality, and business cycle were the key determinants of youth unemployment. The study also found that family background and social status have a great impact on youth unemployment in the country. The result can be explained as if parents or one of the parents have low education or are illiterate, without skills and qualifications, they live in poverty and are likely to duplicate the same to the youth people.

Ingham (1989) found that a Certificate of Secondary Education may have prime importance in securing employment for the youths. Rodriguez-Modroño (2019) found that in addressing Spanish youth unemployment, gender and some other structural differences have been ignored in policy debates, and as a result, it may have led to certain inequalities, including high youth unemployment and gender inequalities. Ordine and Rose (2015) found that the so-called "overeducated" youths often suffer from long spells of unemployment compared to the cohort of youths whose education is well-matched with potential employment.

With related to entrepreneurship and its importance to enhance job creation Millman et al. (2008) found that the introduction of entrepreneurship education in the Chinese educational system in the form of the "Know about your business" (KAB) program was very successful. About $43.9 \%$ of students who participated in this program were "delighted" while $(52.6 \%)$ of students were satisfied. Therefore, the introduction of entrepreneurship in the education system can go a long way to solving the unemployment program in general, especially youth unemployment. On the other hand, Bignotti et al. (2018) have found that young South Africans have an entrepreneurial endowment and support programs and, therefore, in such a set of "community support" and the "need for achievement," entrepreneurship has the potential to solve the youth unemployment.

With, related to Jordan, Kreishan, and Alhawarien (2014), pointed out that one of the main reasons for increasing youth unemployment in the country is the lack of consistency between learned skills and required skills labor market. Similarly, Mryyan (2014) indicates that Jordanian youth lack academic and non-cognitive focus, which are important elements of the labor market and the lack of a clear link between education outcomes and the labor market. This result is consistent with the findings of Brown et al. (2014) and Ayhan (2016), who pointed out that demographic factors, gender, and incompatibility between training systems and the labor market, as well as the existence of some problems in the education system, are among the most important reasons that lead to increased youth unemployment. Gurbuzer and Ozel (2009) concluded that the progress in educational levels is not a 
condition for not falling into unemployment, and although there is no gender gap in educational levels among youth, this gap still exists in the labor market.

In the same context, a recent study by (OECD 2018) focused on the impact of education and experience on youth employment distribution in Jordan. The study concluded that although Jordan, over the last two decades, has made considerable socio-economic progress. Young Jordanians face multiple and interconnected challenges that require a comprehensive approach to youth challenges. However, this literature review showed that different researchers have been interested in finding the determinants of youth employment in developed and developing countries. However, what factors contribute to youth unemployment, given the current economic and social context, is still very important to the government, policymakers, and scholars. Therefore, our research seeks to fill this gap in the literature by considering several key variables. This study mainly examines the determinants of youth employment in Jordan and suggests the possible ways to tackle it.

\section{Methodology and Data}

The research question was prepared to examine the overall characteristics and determinants that affect youth unemployment status in Jordan. The paper uses the multinomial logistic regression model (MLM), which generalizes logistic regression by allowing more than two discrete outcomes. This estimation procedure is used when there are more than two categories, and the dependent variable is categorical, which is the dependent variable falls into any one of a set of categories that cannot be ordered in any meaningful way (Greene, 2003). The MLM predicts the probabilities of a categorically distributed dependent variable's different possible outcomes, given a set of independent variables. The model's choice is based on its relevance in handling categorical data and its frequency usage in studies related to the labor market and unemployment problems. This estimation procedure helped us shed light on youth unemployment, identify its determinants, and estimate their effects. Generally, the logistic regression model explained is in the following way:

$\ln \left(\frac{P_{i}}{1-P_{i}}\right)=X_{i} \beta+u_{i}$

Where $\mathrm{P}$ is the probability of an event occurring, $\mathrm{X}$ is indicating the set of explanatory variables of the model, $\beta$ is a vector of logit coefficients (log odds) to be estimated, $\mathrm{u}$ is a random error term, $\mathrm{i}$ stands for a case (an individual), and $\ln$ is the natural $\log$. The interpretation of signs of $\log$ odds is fairly similar to ordinary least regression. Overall, the negative sign of log odds means that the increase in a covariate will decrease the probability $\mathrm{P}$, and vice versa, in case of the positive sign, holding all other covariates in the model constant. Exponentiating predicted log-odds yields odds ratios, which do not take a negative value (i.e., ranging from 0 to positive infinity). Having exponentiated a log odd with a value of zero, one will get 
the unity. In other words, an odds ratio of (1) means that the explanatory variable exerts no influence on the probability of an event occurring. Hence, odds ratios with values greater than and lower than unity correspond to positive and negative influences, respectively.

The study employs the micro-level data from the Jordan labor market panel survey (JLMPS) (2016). In this paper, the dependent variable of the model is the youth employment status in Jordan. The explanatory variables (Independent variables) of the model include education level, gender, location and marital status, and father's educational level. The study adopts a definition of youth as a person aged between 15-34 years. The study variables are categorical, and the dependent variable was categorized into more than two categories. Since the test of one category does not depend on another's test, the study used the MLM test, as it is appropriate to achieve the study objective

Table 1. Gender distribution of population aged (15-34) in Jordan for 2016

\begin{tabular}{|r|r|r|r|r|r|r|}
\hline Gender & Freq. & Mean & Std.dev. & Min & Max & Percent \\
\hline Male & 6149 & 1 & 0 & 1 & 1 & $\mathbf{5 1 . 1 7}$ \\
\hline Female & 5868 & 2 & 0 & 2 & 2 & $\mathbf{4 8 . 8 3}$ \\
\hline Total & 12017 & 23.74544 & 5.579488 & 15 & 34 & $\mathbf{1 0 0 \%}$ \\
\hline
\end{tabular}

Source: Author's calculations based on (JLMPS) (2016) results.

To achieve the study's objectives, the individuals currently enrolled in education were excluded, as shown in Table 2. The Table shows the number of individuals in the same age group in the year 2016 were (7391), (1081) of them were unemployed, (3295) were out of the labor force, the estimated number of employed was about (3015) as shown in the table below.

Table 2. Distribution of population aged (15-34) who were not enrolled in education

\begin{tabular}{|r|r|r|}
\hline $\begin{array}{r}\text { Work status } \\
\text { (Search required) }\end{array}$ & $\begin{array}{r}\text { Individuals currently } \\
\text { not studying }\end{array}$ & $\begin{array}{r}\text { Percentage } \\
(\mathbf{\%})\end{array}$ \\
\hline Employed & 3015 & $\mathbf{4 1}$ \\
\hline Unemployed & 1081 & $\mathbf{1 5}$ \\
\hline out of labor force & 3295 & $\mathbf{4 4}$ \\
\hline Total & 7391 & $\mathbf{1 0 0 \%}$ \\
\hline
\end{tabular}

Source: Author's calculations based on (JLMPS) (2016) results.

Our analysis focused on Jordan's youth employment data using published raw data from the (JLMPS) issued by the DOS in 2016. Those surveys included the employed and the unemployed and those outside the labor force during the survey period. To achieve the study's objectives, the age group (15-34) year was targeted, and those who were still studying were excluded. The number of people surveyed in this study from both genders was (7391) for 2016. The sample comprises of $(33,450)$ individuals and gathers detailed individual and household information. The size of 
the study sample represents about $(25 \%)$ of the population, and the male to female ratio was $(51.8 \%)(48.2 \%)$, respectively.

According to (JLMPS, 2016) as summarized in Table 3, (41\%) of the youth are employed, (16.5\%) are male while $(14.1 \%)$ are female. Statistics show that among the employed youth $(25.3 \%)$ have basic education and $(31 \%)$ have secondary education while $(40.9 \%)$ of employed youth completed a university degree. On marital status, statistics show that $(39.9 \%)$ of employed youth are single while $(41.7 \%)$ are married. Whereas statistics on youth unemployment showed that $(21.2 \%)$ of youth unemployed were single, and only $(8.3 \%)$ of youth are married, as shown in Table 3.

Table 3. Description of Socio-economic and Demographic factors affecting occupational Status of Jordanian youths (JLMPS, 2016)

\begin{tabular}{|c|c|c|c|c|}
\hline Study variables & $\begin{array}{r}\text { Employed } \\
(\%)\end{array}$ & $\begin{array}{l}\text { Unemployed } \\
\qquad \%)\end{array}$ & $\begin{array}{r}\text { Out of labor } \\
\text { force }(\%)\end{array}$ & $(\%)$ \\
\hline $\operatorname{Sex}(\%)$ & ---- & ---- & ---- & ---- \\
\hline Male & 16.5 & 14.6 & 19.8 & 51.8 \\
\hline Female & 14.1 & 14.6 & 71.2 & 48.2 \\
\hline Educational level (\%) & ---- & ---- & ---- & ---- \\
\hline Basic education & 25.3 & 6.3 & 68.4 & 4.9 \\
\hline Secondary & 31 & 10 & 59 & 12.6 \\
\hline Post-secondary & 42.4 & 11.3 & 46.3 & 38.4 \\
\hline University & 40.9 & 8.2 & 50.9 & 13.7 \\
\hline (Region\%) & $\begin{array}{l}----- \\
-1\end{array}$ & ----- & $\begin{array}{ll}---- \\
---\end{array}$ & $\begin{array}{c}---- \\
-1\end{array}$ \\
\hline Middle & 39.2 & 10.2 & 50.6 & 47.7 \\
\hline South & 44.1 & 16 & 39.9 & 33.5 \\
\hline North & 39 & 23.4 & 37.6 & 18.8 \\
\hline Marital status (\%) & ---- & ---- & ---- & ---- \\
\hline Single & 39.9 & 21.2 & 38.9 & 48.8 \\
\hline Married & 41.7 & 8.3 & 50 & 51.2 \\
\hline FatherEducation (\%) & ---- & ---- & ---- & ---- \\
\hline Basic education & 41.2 & 13.5 & 46.3 & 73.8 \\
\hline Secondary & 41 & 16 & 53 & 12.6 \\
\hline Post-secondary & 43.4 & 19.6 & 37 & 5.4 \\
\hline University & 45 & 19 & 36 & 8.2 \\
\hline
\end{tabular}

Source: Author's calculations based on (JLMPS) (2016) results.

\section{Results and Discussion}

The study utilized the (JLMPS) using (MLM). The Stata software was also used to analyze the data and extract results. This section tests if youth employment in Jordan is influenced by education level, gender, location, marital status, educational level of the father, and the geographical region. The employment status should be the outcome variable, which is related to the different categories analyzed. Before giving 
an interpretation of the model results, we should check whether the model fits the data well. We first analyzed whether the independent variables in our model have a significant relationship with the dependent variable. The analyses were conducted using a Chi-Square test. This was necessary for determining the ability of the model to predict the dependent variable accurately. The test results imply that the independent variables added to the model have a relationship to the dependent variable; hence they contribute to reducing error in the model and can accurately predict the dependent variable of the model. The likelihood ratio, as presented in Table 4, tells us that our model as a whole, fits significantly better than an empty model (that is, a model with no predictors) as represented in the table. This leads us to conclude that the model is in line with what was expected: that youth employment in Jordan is influenced by gender, education levels, geographical location, and the father's education.

\section{Table 4. Model Testing}

\begin{tabular}{|r|r|r|r|}
\hline \multicolumn{3}{|c|}{ Model Fitting Information } \\
\hline Wald chi2 & Prob > chi2 & Log pseudo likelihood & Pseudo (R2) \\
\hline 1026.04 & 0.0000 & -1184615.6 & 0.2759 \\
\hline
\end{tabular}

Source: Author's calculations based on (JLMPS) (2016) results.

Table 5 reports the results from the multinomial logit regression in relative risk ratios (RRR). All of the variables included in the regression are kept constant, i.e., controlled against the benchmark group in the analysis. From table 5 above, the variables that have a statistically significant relationship to distinguish unemployed youth from employed youth were sex, marital status, education level, and region. So, all variables were statistically significant, except for the fathers' educational level were statistically insignificant. Gender is one of the important factors responsible for variations in individuals' positions in the labor market. Sex of the Jordanian youth was one of the demographic variables that were found to be related to employment status. The results show that $(76 \%)$ of females are less likely to be employed over being unemployed. This indicates that males have a higher chance of finding a job than females, which confirms that female unemployment is more severe than male unemployment. The $(\mathrm{RRR}=0.24)$ test specified a statistically significant relationship between sex and employment status. These studies also support the findings that women's youth were discriminated against; therefore, males had a high chance of being employed than female youth. These results were consistent with the findings presented in previous studies such as Isengard (2003) in Germany, Mlatsheni and Rospabe (2002), Msigwa, and Kipesha (2013) in Tanzania, which reported that gender was among the key factor for youth unemployment. These studies also reported that male youth have a high chance of being employed over being unemployed compared to female youth.

As far as the relationship between marital status and youth employment status is concerned, the unemployment percentage was higher for single youth $(21 \%)$ than married youth. The results on the role of marital status in differentiating youth person 
employment status show that; being married youth increased the likelihood that the youth person would be employed over being unemployed. The opportunity for married individuals to be employed over being unemployed is equal to nearly (2) times compared to single individuals. This is explained by the fact that married youth have more responsibilities of taking care of the family, which requires them to work while most of the single youth still depend on the parents hence less motivated to be employed. The educational status could be a key factor that affects the employment status of youth in the country. Those people having a high educational level or highly educated were more productive, and they have relatively highly opportunistic, and they were highly salaried comparatively. Instead, when the youth lacked essential skills and knowledge, the probability of being unemployed is greater. The findings on the impact of education level on the youth employment status show that compared to basic education, the improvement in the educational level of individuals increases the opportunity of being employed over being unemployed. The impact of youth education on their employment status shows that the youth who have completed the secondary level have a chance of being employed (1.55) times over those at the basic education level. Individuals at the post-secondary level of education have a chance of being employed (5) times over those at the basic education level. The youth who have completed the university degree can be employed (9.5) times over those at the basic education level. The findings on the impact of education level support the finding by Msigwa and Kipesha (2013) in Tanzania, Isengard (2003) in Germany, Bruno, and Cazes (1998) in France, which all indicated that skills and education were important determinant factors in employment.

Tabel.5:Multinomial-logistic-regression/parameter-Estimats

\begin{tabular}{|c|c|c|c|c|c|c|c|c|}
\hline & Out of labor force (Ref.) & RRR & Coefficient s & Std. Err & $\mathbf{Z}$ & $\mathbf{P}>\mid \mathbf{z}$ & {$[95 \% \mathrm{C}$} & ff. Interval] \\
\hline \multirow{14}{*}{ Employed } & Sex (Ref.=Male) & 0.0240176 & -3.72897 & 0.140812 & -26.48 & $0.000^{*}$ & -4.004957 & -3.452984 \\
\hline & Education level (Ref. =Basic Edu.) & & & & & & & \\
\hline & Secondary & 1.547052 & 0.4363509 & 0.1497867 & 2.91 & $0.004 * *$ & 0.1427743 & 0.7299275 \\
\hline & post-secondary & 5.126059 & 1.634337 & 0.1954913 & 8.36 & $0.000^{*}$ & 1.251181 & 2.017493 \\
\hline & university + & 9.516519 & 2.253029 & 0.1724756 & 13.06 & $0.000^{*}$ & 1.914983 & 2.591075 \\
\hline & Region (Ref.=Middle) & & & & & & & \\
\hline & South & 1.427446 & 0.3558868 & 0.1078169 & 3.30 & $0.001 *$ & 0.1445696 & 0.567204 \\
\hline & North & 1.474817 & 0.3885337 & 0.1337634 & 2.90 & $0.004 *$ & 0.1263623 & 0.650705 \\
\hline & Marital status (Ref. $=$ Single) & 1.9885 & 0.6873808 & 0.1125997 & 6.10 & $0.000^{*}$ & 0.4666893 & 0.9080722 \\
\hline & Father education $(\operatorname{Ref}=$ Basic Edu $)$ & & & & & & & \\
\hline & Secondary & 0.7301703 & -0.3144775 & 0.1558408 & -2.02 & $0.044 *$ & -0.6199198 & -0.0090353 \\
\hline & post-secondary & 0.8985867 & -0.1069321 & 0.2273371 & -0.47 & 0.638 & -0.5525046 & 0.3386404 \\
\hline & university+ & 1.142514 & 0.1332311 & 0.2128598 & 0.63 & $0.531 *$ & -0.2839664 & 0.5504287 \\
\hline & Constant & 20.43308 & 3.017155 & 0.299452 & 10.08 & $0.000^{*}$ & 2.43024 & 3.60407 \\
\hline \multirow{11}{*}{ Unemployed } & Sex (Ref.=Male) & 0.1583034 & -1.843242 & 0.1535763 & -12.00 & $0.000 *$ & -2.144246 & -1.542238 \\
\hline & Education level (Ref.=Basic Edu.) & & & & & & & \\
\hline & Secondary & 0.9036122 & -0.101355 & 0.2142885 & -0.47 & 0.636 & -0.5213527 & 0.3186427 \\
\hline & post-secondary & 5.973752 & 1.787375 & 0.2536521 & 7.05 & $0.000^{*}$ & 1.290226 & 2.284524 \\
\hline & university+ & 10.99191 & 2.397159 & 0.1742025 & 13.76 & $0.000 *$ & 2.055729 & 2.73859 \\
\hline & Region (Ref. =Middle) & & & & & & & \\
\hline & South & 1.873587 & 0.6278549 & 0.1345445 & 4.67 & $0.000 *$ & 0.3641525 & 0.8915574 \\
\hline & North & 3.184144 & 1.158183 & 0.1818267 & 6.37 & $0.000^{*}$ & 0.8018096 & 1.514557 \\
\hline & Marital status $($ Ref. $=$ Single) & 0.3316312 & -1.103732 & 0.1818267 & -8.76 & $0.000^{*}$ & -1.350596 & -0.8568674 \\
\hline & Father education $(\operatorname{Ref}=$ BasiEdu. $)$ & & & & & & & \\
\hline & Secondary & 0.9980636 & -0.0019383 & 0.1837401 & -0.01 & 0.992 & -0.3620623 & 0.3581857 \\
\hline
\end{tabular}




\begin{tabular}{|l|l|l|l|l|l|l|l|}
\hline post-secondary & 1.024319 & 0.024028 & 0.2376056 & 0.1 & 0.919 & -0.4416704 & 0.4897264 \\
\hline university+ & 0.9219278 & -0.0812884 & 0.225046 & -0.36 & 0.718 & -0.5223705 & 0.3597937 \\
\hline Constant & 8.631281 & 2.155393 & 0.3748073 & 5.75 & $0.000^{*}$ & 1.420784 & 2.890002 \\
\hline
\end{tabular}

Note: *Significance $(p<0.01)$, **Significance $(p<0.05)$, ref=Reference category. Source: Author's calculations based on (JLMPS) (2016) results.

Finally, in this study, youth location was one of the demographic variables region have a chance almost of (1.5) times of being employed over being unemployed compared to the middle arias. Finally, father's educational status was regarded as a variable that determine socio-economic profile of the Jordanian youths. Quite unexpectedly, the association between youth employment status and their fathers' educational level was found to be statistically insignificant.

\section{Conclusion and Recommendations}

The study aimed to examine the factors that determine youth unemployment in Jordan and suggest a way forward towards reducing the problem. The study uses (MLM) to analyze the determinants of unemployment in Jordan. The study used secondary data provided by the (DOS) labor market panel survey (JLMPS) of 2016, the most current survey. Our research results concluded that for youth (aged 15-34 years), gender, geographical location, education level, marital status are all significant factors in explaining the difference in youth employment status in Jordan.

Although there is no gender gap in the youth education level, our analysis in Jordan showed that gender-related differences remain significant in Jordan's labor market participation. Male youth stand a better chance of being employed over being unemployed as compared to female youth. The youth's regional location is found to be a significant factor in which youth people living in the southern regions are more likely to be unemployed than being employed. The results on youth education status show that the youth who have completed the university degree can be employed (9.5) times over of those who are at the basic education. The study findings also indicate that marital status was a significant determinant factor in which married youth increased the likelihood that the youth would be employed over being unemployed.

Based on the findings, an attempt has been made to put forward some policy implications and recommendations; first, the government and policymakers should review job market laws and regulations to promote youth's smooth transition from education to the job market. The study's findings show that youth with primary school education are likely to be unemployed over being employed. Therefore, the government needs to create specific interventions, especially in creating effective vocational education and strengthening job market regulation relating to youth people. The study's findings also show that gender imbalance is still a problem in the labor market in Jordan; the results indicate that male youth are at the advantage side to be employed over being unemployed. The Government should consider expansion 
of employment programs, particularly programs targeted towards females as they are more likely to be unemployed than males. The government should also encourage the private sector to invest more in industries with high employment creation capacity through a joint venture with those requiring highly labor-intensive, such as the manufacturing and tourism sectors.

Moreover, labor market information plays an important role in providing the efficiency of the labor market. The study recommends that the (DOS) should improve their data collection and categorization of youth people in Jordan. So far, some of the data presented by the integrated labor force survey are very general, such as education level and skills, which do not give details on youth with skills or vocational education. Further analysis of Jordan's differences from the rest of Arabic Middle Eastern countries should be helpful to have a better understanding of the labor market outcomes. This analysis should study the Jordanian economy by a macro-economic structure and its relation to the unemployment problem. Finally, it is important to study the effect of COVID-19 on the labor market and particularly on youth unemployment in Jordan.

\section{References:}

Andrews, M., Bradley, S. 1997. Modelling the transition from school and the demand for training in the United Kingdom. Economica, 64(255), 387-413.

Ayhan, F. 2016. Youth unemployment as a growing global threat. Actual problems of the economy, (7), 262-269.

Bignotti, A., le Roux, I. 2018. Discovering the entrepreneurial endowment of the youth. African Journal of Economic and Management Studies, 9(1), 14-33.

Brown, R.A., Constant, L., Glick, P., Grant, A.K. 2014. Youth in Jordan: Transitions from Education to Employment. RAND Corporation.

Bruno, C., Cazes, S. 1998. French youth unemployment: An overview. Employment and Training Department, International Labour Office, Geneva.

Caroleo, F.E., Pastore, F. 2007. A note on youth unemployment in the EU. Annals of the University of Petrosani, Economics, 7.

Choudhry, M.T., Marelli, E., Signorelli, M. 2012. Youth unemployment rate and impact of financial crises. International Journal of Manpower, 33(1), 76-95.

Clark, K.B., Summers, L.H. 1982. The dynamics of youth unemployment, In the youth labor market problem: Its nature, causes, and consequences. University of Chicago Press, 199-234.

Contini, B. 2010.Youth employment in Europe: institutions and social capital explain better than mainstream economics. Institute of Labor Economics, IZA Discussion Paper No. 4718, 1-31.

Department of Statistics. 2016. Jordan labor market panel survey (JLMPS). Amman, Jordan.

Department of Statistics. 2016. Year Book, issue No. 67. Amman, Jordan.

Department of Statistics. 2019. Unemployment indicators. Amman, Jordan.

Dimian, G.C. 2011. The role of education in explaining youth labor market imbalances in CEE Countries. Journal on efficiency and responsibility in education and science, 4(3), 105-115. 
Dimitrov, J. 2012. Youth unemployment in Bulgaria. Friedrich-Ebert-Stiftung, Internat, Dialogue.

Feldstein, M., Ellwood, D.T. 1979. Teenage unemployment: What is the problem? National Bureau of Economic Research, No. 0393.

Green, A.E., Owen, D., Wilson, R. 2001. Regional differences in labor market participation of young people in the European Union. European urban and regional studies, 8(4), 297-318.

Greene, W.H. 2002. Econometric Analysis, Fifth Edition. McGraw Hill, NY.

Gurbuzer, L.Y., Ozel, M.H. 2009. Youth Employment in the Hashemite Kingdom of Jordan: Characteristics and Determinants. Retrieved from: http://ucwproject.org/attachment/gurbuzer_ist.pdf.

Ingham, M. 1989. Education and youth unemployment: a reappraisal. Journal of Economic Studies, Vol. 16, No. 3.

International Labour Organization (ILO). 2006. Global Employment Trends for youth. Geneva.

International Labour Organization (ILO). 2011. Global Employment Trends. Report, Geneva.

Isengard, B. 2003. Youth unemployment: Individual risk factors and institutional determinants. A case study of Germany and the United Kingdom. Journal of Youth Studies, 6(4), 357-376.

Keen, D. 2012. Greed and grievance in civil war. International Affairs, 88(4), 757-777.

Kreishan, F., Alhawarin, I. 2014. Youth Unemployment in Jordan: What can be learned for the future. Zarqa Journal for Research and Studies in Humanities, 14(1), 22-31.

Millman, C., Matlay, H., Liu, F. 2008. Entrepreneurship education in China: a case study approach. Journal of Small Business and Enterprise Development, 15(4), 802-815.

Mlatsheni, C., Rospabé, S. 2002. Why is youth unemployment so high and unequally spread in South Africa? University of Cape Town.

Mryyan, N. 2014. Demographics, labor force participation, and unemployment in Jordan. The Jordanian labour market in the new millennium, 39-63.

Msigwa, R., Kipesha, E.F. 2013. Determinants of youth unemployment in developing countries: Evidences from Tanzania. Journal of Economics Sustainable Development, 4(14), 67-76.

Ndagijimana, J., Nzasingizimana, T., Heshmati, A. 2018. An Analysis of the Determinants of Youth Employment in Rwanda. UKH Journal of Social Sciences, 2(2), 1-10.

OECD. 2006. Employment Outlook 2006: Boosting Jobs and Incomes. Organization for Economic Co-operation and Development. Paris, France.

OECD. 2018. Youth Well-being Policy Review of Jordan. EU-OECD Youth Inclusion Project, Paris, France.

Ordine, P., Rose, G. 2015. Educational mismatch and unemployment scarring. International Journal of Manpower, 36(5), 733-753.

Pozzoli, D. 2009. The transition to work for Italian university graduates. Labour, 23(1), 131169.

Prince, H., Halasa-Rappel, Y., Khan, A. 2018. Economic growth, youth unemployment, and political and social instability: A study of policies and outcomes in post-Arab spring Egypt, Morocco, Jordan, and Tunisia. UNRISD Working Paper, No. 2018-12.

Rahman, M., Farooq, M.O., Selim, M. 2020. Mitigating Educated Youth Unemployment in Bangladesh. Journal of Developing Areas, forthcoming in Vol. 55, No.1.

Rodriguez-Modroño, P. 2019. Youth unemployment, NEETs and structural inequality in Spain. International Journal of Manpower, Vol. 40, No. 3, 433-448. 
Speckesser, S.S., Gonzalez Carreras, F.J., Kirchner Sala, L. 2019. Active labour market policies for young people and youth unemployment: An analysis based on aggregate data. International Journal of Manpower, Vol. 40, No. 8, 1510-1534.

UNICEF. 2005. The State of Pacific Youth. Noumea, Secretariat of the Pacific Community.

Viitanen, T. 1999. Estimating the probability of youth unemployment. An extended essay for a BsocSC in economics and statistics. Inglaterra, CEP London School of Economics, $1-21$. 